\title{
Identification of Staphylococcus species isolated from preputium of Aceh cattle based on 16S rRNA gene sequences analysis
}

\author{
Muhammad Hambal ${ }^{1}$, Masda Admi ${ }^{2,3}$, Safika Safika ${ }^{4}$, Wahyu Eka Sari ${ }^{5,6}$, Teuku Reza Ferasyi ${ }^{6}$, Dasrul Dasrul ${ }^{7}$,
} Ummu Balqis ${ }^{8}$ and Darmawi Darmawi ${ }^{2,9}$

1. Laboratory of Parasitology, Faculty of Veterinary Medicine, Universitas Syiah Kuala, Banda Aceh, Aceh, Indonesia;

2. Laboratory of Microbiology, Faculty of Veterinary Medicine, Universitas Syiah Kuala, Banda Aceh, Aceh, Indonesia;

3. Department of Mathematics and Applied Sciences, Universitas Syiah Kuala, Darussalam, Banda Aceh, 23111, Indonesia; 4. Department of Veterinary Infectious Diseases and Veterinary Public Health, Faculty of Veterinary Medicine, IPB University, JI. Agatis Dramaga, Bogor, 16680, West Java, Indonesia; 5. Laboratory of Research, Faculty of Veterinary

Medicine, Universitas Syiah Kuala, Banda Aceh, Aceh, Indonesia; 6. Laboratory of Veterinary Public Health, Faculty of

Veterinary Medicine, Universitas Syiah Kuala, Banda Aceh, Aceh, Indonesia; 7. Laboratory of Reproduction, Faculty

of Veterinary Medicine, Universitas Syiah Kuala, Banda Aceh, Aceh, Indonesia; 8. Laboratory of Pathology, Faculty of Veterinary Medicine, Universitas Syiah Kuala, Banda Aceh, Aceh, Indonesia; 9. Laboratory of Biomedical Science, Faculty of Public Health, University of Teuku Umar, Meulaboh, Aceh, Indonesia.

Corresponding author: Darmawi Darmawi, e-mail: darmawi@unsyiah.ac.id

Co-authors: MH: hambal.m@unsyiah.ac.id, MA: admi.masda@gmail.com, SS: fikakhan@yahoo.com, WES: wahyueka_sari@unsyiah.ac.id, TRF: teuku_rezaferasyi@unsyiah.ac.id, DD: dasrul.darni@yahoo.com,

UB: ummu.balqis@unsyiah.ac.id

Received: 04-03-2019, Accepted: 29-08-2019, Published online: 08-10-2019

doi: 10.14202/vetworld.2019.1540-1545 How to cite this article: Hambal M, Admi M, Safika S, Sari WE, Ferasyi TR, Dasrul D, Balqis U, Darmawi D (2019) Identification of Staphylococcus species isolated from preputium of Aceh cattle based on 16S rRNA gene sequences analysis, Veterinary World, 12(10): 1540-1545.

\begin{abstract}
Aim: This research aimed to identify Staphylococcus species isolated from preputial swabs of healthy Aceh cattle, based on $16 \mathrm{~S}$ ribosomal RNA gene analysis.

Materials and Methods: The bacterium was isolated from preputial swabs of healthy Aceh cattle. The total DNA from the isolated bacteria was extracted using the Genomic DNA Mini Kit followed by polymerase chain reaction (PCR) amplification of the 16S rRNA gene. The product of PCR amplification was then sequenced and aligned to the known sequences in the GenBank database by multiple alignments and was also analyzed by bioinformatics software to construct a phylogenetic tree.

Results: The results revealed that the bacterial isolate 3A had genetically closed relation to Staphylococcus pasteuri with $<97 \%$ maximum identity. Data derived from the phylogenetic tree revealed that the bacterial isolate $3 \mathrm{~A}$ was also related to Staphylococcus warneri, yet, it shows a different evolutionary distance with the ancestors (S. pasteuri).
\end{abstract}

Conclusion: The results of this research suggested that the bacterium 3A, isolated from preputial swabs of healthy Aceh cattle, is a Staphylococcus species.

Keywords: 16S rRNA gene, Aceh cattle, phylogenetic tree, polymerase chain reaction, Staphylococcus pasteuri.

\section{Introduction}

There is a permanent need for dairy farms and their development in Indonesia, as it is inseverable and integral part of the farming system. There are about 14.90 million cattle, contributing to $4.80 \%$ of the national Growth Domestic Product [1]. Aceh cattle are one of several indigenous Indonesian cattle and are acknowledged as an Indonesian domestic breed with many positive characteristics for tropical climates. The population of Aceh cattle was recorded to be more than 511 thousand in 2015 and is concentrated in the Aceh Province [2]. Aceh cattle play a major role in beef production, so they are usually referred to as beef

Copyright: Hambal, et al. Open Access. This article is distributed under the terms of the Creative Commons Attribution 4.0 International License (http://creativecommons.org/licenses/ by/4.0/), which permits unrestricted use, distribution, and reproduction in any medium, provided you give appropriate credit to the original author(s) and the source, provide a link to the Creative Commons license, and indicate if changes were made. The Creative Commons Public Domain Dedication waiver (http:// creativecommons.org/publicdomain/zero/1.0/) applies to the data made available in this article, unless otherwise stated. cattle, besides being able to produce milk. They are also the principle animals for draft work in rice fields. As such, Aceh cattle must be conserved by focusing on diseases caused by animal pathogens to ensure the availability of adequate supplies of Aceh cattle and their products in the future.

Therefore, in this research, we focused on pathogenic bacteria which are a potential risk to reproduction organs, causing widespread disease, especially during Aceh cattle breeding. Microbial contamination affects motility, morphology, and various semen quality parameters [3]. Preputium infections caused by bacteria have been a primary concern for cattle breeders, as they can affect the reproductive performance of cattle. During the breeding season, the prepuce bacteria may be transmitted to other cattle, playing an important role in serious diseases. Various types of bacteria present in the soil, bedding, and manure can cause contamination with entry through the preputial orifice into the preputium cavity of cattle; this can occur frequently. In previous studies, 
several authors have reported potential sources of preputium infection [4-6].

There are numerous studies regarding Staphylococcus pasteuri as a potential pathogen found in various environmental conditions. The spread of $S$. pasteuri in plant food environments and animals has been reported by several authors and their studies described that vegetables $[7,8]$, and leafy vegetables, including perilla leaf, chicory, and lettuce from local markets in South Korea [8], pig farms in the Netherlands [9], and bovine mastitis from Brazilian dairy herds [10] were contaminated or caused by $S$. pasteuri. In our previous investigation of cellulolytic Enterobacter [11], and cellulolytic Bacillus [12], both bacteria were found in the rumen of Aceh cattle. Recently, in the preputial swabs of Aceh cattle, we found prevalence of $8.0 \%$ of Escherichia fergusonii identified by phylogenetic 16S rRNA analysis [13]. The 16S rRNA gene has highly conserved sequences within species and between species of the same genus so that this gene can be used as the common tool for the speciation or identification of bacteria.

Thus, 16S rRNA gene analysis of bacteria from preputial swabs of clinically healthy Aceh cattle needs to be conducted. Our research goal was to identify the bacterium isolate $3 \mathrm{~A}$ isolated from preputial swabs of healthy Aceh cattle, based on molecular identification of the bacterial 16S rRNA gene by bioinformatic analysis and construction of a phylogenetic tree.

\section{Materials and Methods}

\section{Ethical approval}

All procedures of this research involving animal care were carried out in accordance with local government guidelines. They were approved by the Animal Ethics Committee of Faculty of Veterinary Medicine, Universitas Syiah Kuala, Aceh, Indonesia (approval No. 014/KEPH-C/III/2017).

\section{Preparation of animals}

Aceh cattle are indigenous animals in Aceh, which are unique in that they are smaller in size than cattle from other regions. The cattle used in this research were male cattle more than 2 years old and in good clinical health. Preputium samples were obtained from 50 healthy Aceh cattle, kept in Indrapuri Breeding Aceh and Forage Center of Aceh Cattle, Aceh Besar, Indonesia, under sterile, hygienic conditions. The external preputium of the Aceh cattle was sterilized and rinsed with $0.9 \%$ sodium chloride.

\section{Bacterial isolate}

The bacterial isolate 3A was obtained from the collection of Microbiology Laboratory, Faculty of Veterinary Medicine, Universitas Syiah Kuala. This isolate was isolated from preputial swabs samples and cultured on MacConkey agar (Difco Laboratories, USA), then incubated at $37^{\circ} \mathrm{C}$ for $24 \mathrm{~h}$. A total of $1.5 \mathrm{~mL}$ of bacterial culture isolate $3 \mathrm{~A}$ were used for DNA isolation.

\section{DNA isolation}

Total genomic DNA from bacterium isolated from preputial swabs of healthy Aceh cattle was isolated using a gDNA Presto ${ }^{\mathrm{TM}}$ Bacteria Mini kit (Geneaid) with a slightly modified protocol [14]. Purified total genomic DNA $(50 \mu \mathrm{L}, \sim 200 \mu \mathrm{g} / \mathrm{mL})$ was eluted and used as a template for polymerase chain reaction (PCR) amplification following the protocol [11].

\section{PCR amplification of 16S rRNA gene}

The DNA was amplified through PCR using C1000 Thermal Cycler (BIO-RAD) as follows: A DNA template of $30 \mathrm{ng}$ bacterial isolate $3 \mathrm{~A}$ was added to a total reaction mixture $(25 \mu \mathrm{L}$ total) containing $12.5 \mu \mathrm{L}$ of Taq polymerase master mix (KAPA Biosystems, MA, USA), primer forward (5 ' - AGA GT TTGATC(A/C)TGGCTCAG-3') and primer reverse (5'-GGTTAC $(\mathrm{G} / \mathrm{C})$ TTGTTACCTGCCGGA-3') [15], and 10 pmol of each primer. The amplification was performed with initial denaturation step at $95^{\circ} \mathrm{C}$ for $5 \mathrm{~min}$, followed by 30 cycles of amplification [16] $95^{\circ} \mathrm{C}$ for $1 \mathrm{~min}$ denaturation, $50^{\circ} \mathrm{C}$ annealing for $30 \mathrm{~s}$, and $72^{\circ} \mathrm{C}$ extension for $2 \mathrm{~min}$ with a final extension step at $72^{\circ} \mathrm{C}$ for $10 \mathrm{~min}$. The $\sim 1500 \mathrm{bp}$ PCR products were visualized on a $1.2 \%(\mathrm{w} / \mathrm{v})$ agarose gel by electrophoresis in $1 \times$ Tris-Acetate-EDTA buffer pH 8.3 (40 mM Tris-HCl, $40 \mathrm{mM}$ acetate, and $1.0 \mathrm{mM}$ EDTA) and observed with the Gel Doc XR+ System (BIO-RAD).

16S rRNA gene sequencing, analysis of bioinformatics, and construction of the phylogenetic tree

The amplification product was directly sequenced using a DNA sequencer (Macrogen Inc., Korea). The $16 \mathrm{~S}$ rRNA gene sequences data from isolate $3 \mathrm{~A}$ were compared to the GenBank database using the Basic Local Alignment Search Tool (BLAST) software (blastn) available from the National Center for Biotechnology Information (NCBI) (http://www. ncbi.nlm.nih.gov/). The 16S rRNA sequence was analyzed and aligned using the ClustalW program, and the phylogenetic tree was constructed using MEGA 5.05 software (https://www.megasoftware. net/,) $[12,13,17]$, based on the neighbor-joining tree method [18] and refers to the model p-distance, with bootstrap $1000 \times$ [19]. An outgroup for phylogenetic analysis used in this study is an Escherichia coli (Enterohemorrhagic E. coli).

\section{Results}

The bacterial isolate $3 \mathrm{~A}$ isolated from preputial swabs of Aceh cattle produced a single band with expected molecular size of $\sim 1500$ bp (Figure-1). Based on blast results, bacterial isolate $3 \mathrm{~A}$ was closely related to Staphylococcus species with 95-96\% maximum identity. The similarity of bacterial isolate $3 \mathrm{~A}$ with S. pasteuri strain ATCC 51129 (Accession No. NR_114435.1) was 96\% maximum identity, with an E-value 0.0 (Table-1).

The bacterial isolate $3 \mathrm{~A}$ had the highest similarities with $S$. pasteuri at $96 \%$ maximum identity, followed by 
Staphylococcus warneri with 96\% maximum identity, then Staphylococcus devriesei, Staphylococcus epidermidis, Staphylococcus caprae, Staphylococcus capitis, and Staphylococcus lugdunensis, with 95\% maximum identity (Table-1). The phylogenetic tree showed that bacterial isolate $3 \mathrm{~A}$ was closely related to $S$. pasteuri strain ATCC 51129 and separated from the outgroup cluster negative bacteria (E. coli) (Figure-2).

\section{Discussion}

Cases of reproductive organ disorders in cattle are increasing over recent years. These disorders, such as abortions and infertility in cattle, are important problems in the cattle industry; they can be caused by several various factors, such as physical, biological, chemical, and environmental agents [20]. The infectious agents in animal reproductive organs, such as bacteria, are known to have a direct effect on cattle reproductive health. Its complexity can be increased

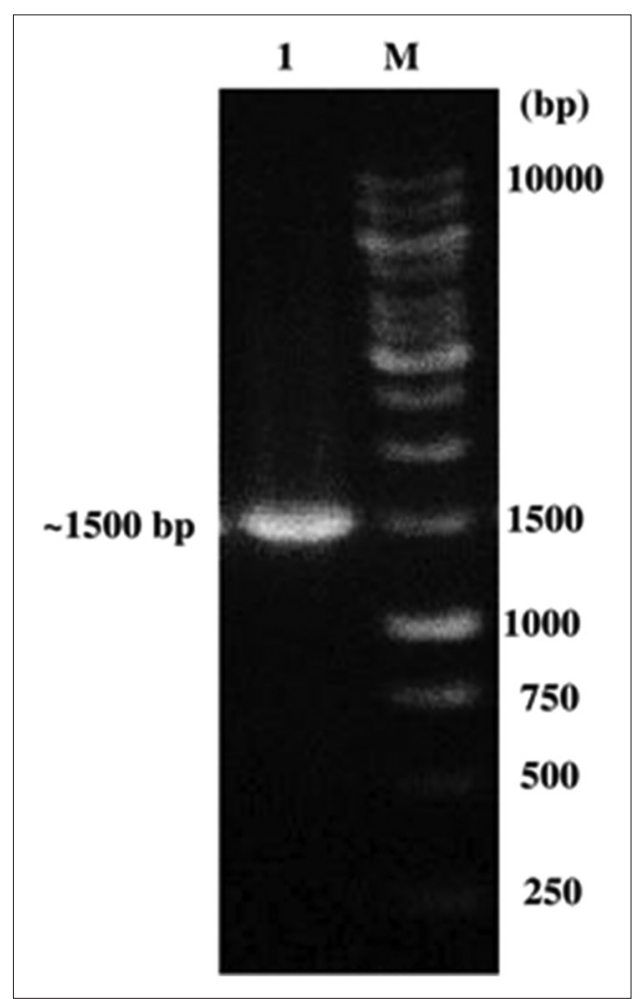

Figure-1: Polymerase chain reaction amplification product on Agarose gel (1\%) ( 1500 bp). Lane 1: Bacterial isolate $3 \mathrm{~A}$; lane 2: Marker $1 \mathrm{~Kb}$. by preputial bacteria which can ultimately determine the overall animal's health. In previous research, each animal appears to have different bacterial communities. For example, Yoo [21] reported that pathogenic bacteria such as Brucella abortus, Leptospira interrogans, Campylobacter fetus, Salmonella spp., and Listeria monocytogenes are involved in reproductive disorders in bovines, including abortion and sterility in cattle. In addition, bovine brucellosis due to $B$. abortus results in infertility in male cattle and abortion in female cattle which are infected and release bacteria in their semen [22,23]. Haapala et al. [24] reported semen as a source of Mycoplasma bovis mastitis in dairy farms. Staphylococcus spp. have also been reported from the preputium of healthy dogs [25]. Different microorganisms that contaminate semen samples of cattle bulls include Staphylococcus spp., Micrococcus spp., E. coli, Pseudomonas spp., Corynebacterium spp., Proteus spp., Klebsiella spp., Bacillus spp., and Streptococcus spp. [6].

DNA sequencing techniques are becoming less expensive and increasingly popular in a clinical environment [26]. An analysis of $16 \mathrm{~S}$ rRNA is frequently used in molecular identification and construction of phylogenetic relationship among prokaryotes because the $16 \mathrm{~S}$ rRNA gene is well conserved in bacteria and is large enough for bioinformatics purposes [27]. In 1994, two strains were considered to belong to novel species if they share the $16 \mathrm{~S}$ rRNA gene sequence similarity lower than $97 \%$ and to discriminate two genera if this value was lower than 95\% [28]. The phylogenetic relationship of taxa in phylogenetic trees constructed from the largely conserved 16S rRNA gene sequences confirmed the largely morphological characteristics and classic phenotypes used for classification schemes for species of the genus Staphylococcus [26,29-31]. Based on 16S rRNA gene analysis, it is reported here that bacterial isolate $3 \mathrm{~A}$ is indicated as a novel species with $<97 \%$ maximum identity, E-value 0.0 , and it belonged to Staphylococcus spp. Based on the phylogenetic tree, the bacterial isolate $3 \mathrm{~A}$ was most closely related to $S$. pasteuri strain ATCC 51129.

S. pasteuri strain ATCC 51129 was first reported by Takahashi et al. [30]. Based on phylogenetic analysis, this species was closely related to $S$. epidermidis, S. lugdunensis, Staphylococcus haemolyticus,

Table-1: Percent similarity the sequences of $16 \mathrm{~S}$ rRNA bacterial isolate 3A to Staphylococcus species.

\begin{tabular}{lccc}
\hline References (GenBank) & \% similarity & E-value & Accession no. \\
\hline Staphylococcus pasteuri strain ATCC 51129 & 96 & 0.0 & NR_114435.1 \\
Staphylococcus pasteuri strain ATCC 51129 & 96 & 0.0 & NR_024669.1 \\
Staphylococcus warneri strain AW 25 & 96 & 0.0 & NR_025922.1 \\
Staphylococcus devriesei strain KS-SP & 95 & NR_116627.1 \\
Staphylococcus epidermidis strain NBRC 100911 & 95 & 0.0 & NR_113957.1 \\
Staphylococcus caprae strain DSM 20608 & 95 & 0.0 & NR_119252.1 \\
Staphylococcus capitis spp. urealyticus strain MAW 8436 & 95 & 0.0 & NR_027519.1 \\
Staphylococcus epidermidis strain Fussel & 95 & 0.0 & NR_036904.1 \\
Staphylococcus lugdunensis strain ATCC 43809 & 95 & 0.0 & NR_024668.1 \\
Staphylococcus caprae strain ATCC 35538 & 95 & 0.0 & NR_0244665.1 \\
\hline
\end{tabular}




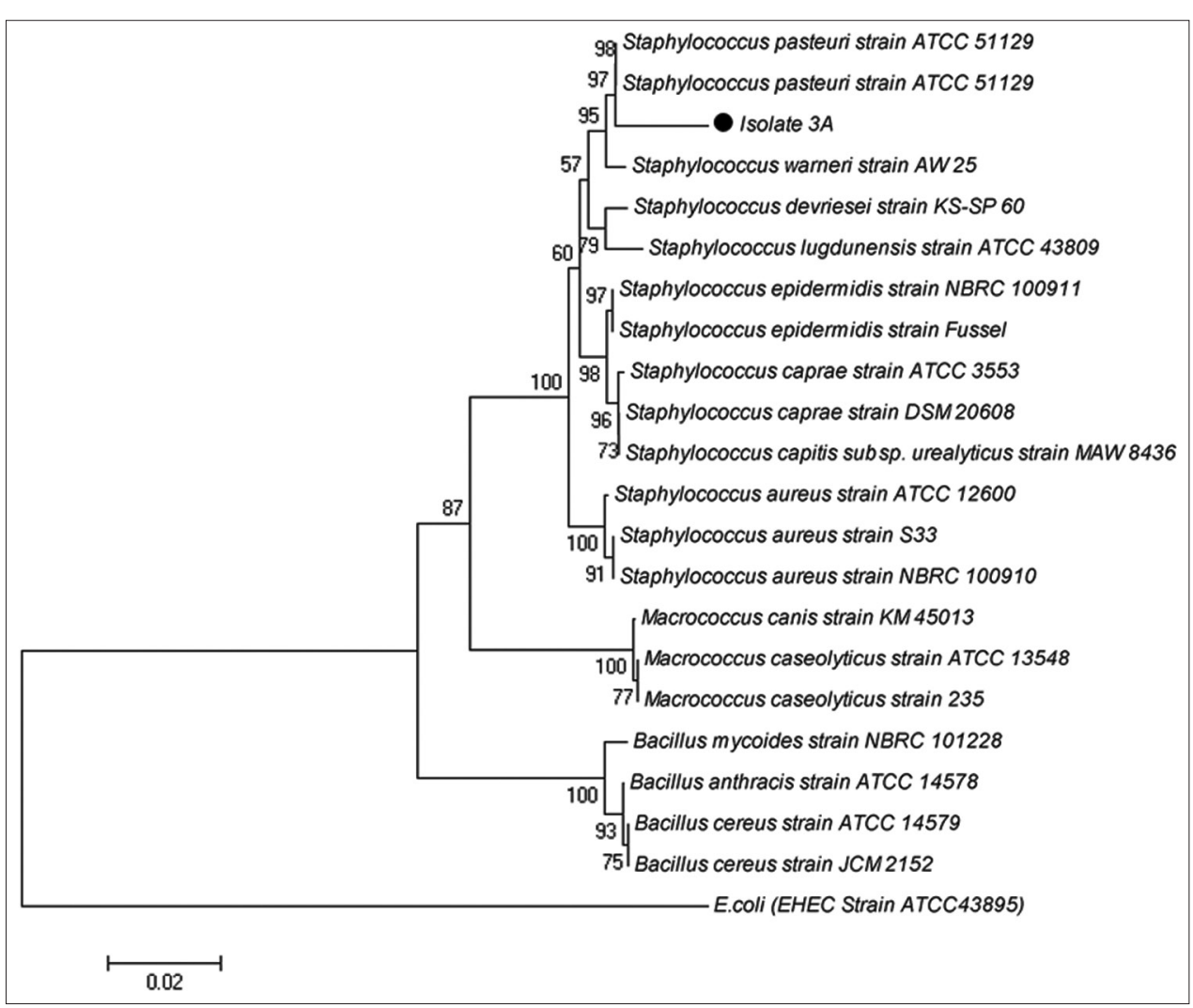

Figure-2: A phylogenetic tree indicating the position of Aceh cattle preputial swab isolate $3 \mathrm{~A}$.

S. capitis, Staphylococcus saccharolyticus, S. caprae, Staphylococcus hominis, and S. warneri. This report supports the results of the phylogenetic tree analysis shown in this study (Figure-2). The characteristics of $S$. pasteuri are that it is cocci, nonmotile, nonsporulating, Gram-positive, with a diameter of 0.5-1.5 $\mu \mathrm{m}$, occurring singly, and the colonies are glistening, smooth, and raised with slightly elevated centers and regular edges. S. pasteuri spp. nov. has been successfully isolated from animals, food specimens, and humans [29].

The findings of the present study are in agreement with the report of various authors which indicated that healthy animals can become subclinical carriers, which can act as reservoirs to transmit $S$. pasteuri. The study by Tulinski et al. [9], conducted on pig farms in the Netherlands, showed that $S$. pasteuri bacteria appeared in nasal swabs of pigs. Regecová et al. [32] reported that $3.8 \%$ of sea fish were positive for $S$. pasteuri. Another investigation in Brazilian dairy herds using milk samples from bovine mastitis cases reported the incidence of $S$. pasteuri as $3.3 \%$ [10]. According to epidemiological analysis, Savini et al. [33] documented that $S$. pasteuri can cross from mammals and lampreys to man.

S. pasteuri is not only crucial for veterinary public health but also is as an agent of human diseases. It has been identified by $16 \mathrm{~S}$ rRNA analysis as causing a bacteremia episode in a leukemia patient [33]. S. pasteuri bacteria are emerging as an agent of nosocomial infections. They are known to contaminate wastewater and drinking water [34], blood products [35], and platelet units from an adult $1^{\text {st }}$-time donor [33]. Furthermore, S. pasteuri was the nosocomial bacteria that were isolated from platelet concentrates [36], in a patient with leukemia [33], from an apheresis platelet product [33], from the community and hospital environments in Thailand [37], hotel rooms [38], and non-health-care environments in London. S. pasteuri has also frequently been found in the food and associated environments, namely, food contact surfaces and hands of food care workers [39].

In particular, $S$. pasteuri may act as a reservoir to transfer genes from coagulase-negative staphylococci to other staphylococcal species. Several studies have demonstrated that antibiotic-resistant genes could be transferred between staphylococcal species. S. pasteuri have been reported to be resistant to several antibiotics, such as methicillin [9,37], streptomycin, and other various antibiotics [38]. S. pasteuri shows resistance to various antimicrobial agents, so it causes difficulties in treatment strategies.

Importantly, although $S$. pasteuri considered a bacterial pathogen under certain circumstances in animals and humans, the bacterium may produce bacteriocin, a ribosomally synthesized peptide that has great potential as an alternative antimicrobial agent. Hong et al. [7] suggested that products released by $S$. pasteuri RSP-1 isolate from leafy vegetables may be utilized to effectively inhibit the growth of Staphylococcus aureus. Recently, Hong et al. [7] successfully characterized and purified 
pasteuricin produced by $S$. pasteuri RSP-1 that act as antimicrobial activity against Gram-positive bacteria including methicillin-resistant $S$. aureus.

$S$. pasteuri can cross from one species to another species, which may play an important role as in it being both a veterinary and human pathogen. Asymptomatic cattle carriers serve as a reservoir for transmission of $S$. pasteuri among ruminant livestock in the cattle farm environment. Host-adapted S. pasteuri can result in endemic disease that is maintained on a farm by carrier animals shedding in the urine and/or semen, indicating significant sources of cross-contamination between cattle. S. pasteuri has already been found in preputium, potentially allowing the bacterium to be spread and can thus pose a significant risk to veterinary public health in cattle breeding farm. To avoid such contaminations, the proper and accurate analysis of the reproductive tract, notably the preputium, is important. The ability of $S$. pasteuri to survive in the preputium shows the need for special care to be taken during the breeding season and collection of semen from cattle to prevent contamination. Moreover, the preputium of cattle should be recognized as a reservoir of some pathogens and as being of great importance to veterinary public health. The hygienic status of the preputium is important for preventing potential pathogenic bacteria transmission through natural mating conditions or artificial insemination.

\section{Conclusion}

The bacterial isolate $3 \mathrm{~A}$ from preputial swabs of healthy Aceh cattle is indicated to be a Staphylococcus species, based on analysis of 16S rRNA gene sequences. The phylogenetic tree showed that this bacterial isolate was related to $S$. pasteuri, and clustered together with S. warneri, Staphylococcus devriesei, S. lugdunensis, S. epidermidis, S. caprae, S. aureus, and $S$. caseolyticus.

\section{Authors' Contributions}

$\mathrm{DD}$ and $\mathrm{MH}$ conceptualized and designed this research. The research was carried out by MA, SS, DDasrul, and TRF. SS and WES analyzed the data and result. $\mathrm{MH}, \mathrm{WES}, \mathrm{UB}$, and DD drafted, revised and finalized the manuscript. All authors read and approved the final manuscript.

\section{Acknowledgments}

We thank Maryulia Dewi, a staff of the Laboratory of Microbiology and Sukmawan Fajar Santosa, a staff of the Research Laboratory, Faculty of Veterinary Medicine, for their assistance and technical help in molecular identification. We also thank Nellita Meutia, a staff of Indrapuri Breeding and Forage Center of Aceh Cattle for their assistance in preparation of preputial swab sample of Aceh cattle. This research was funded by Universitas Syiah Kuala, Indonesia research grant No. 287/UN11/SP/ PNBP/2018.

\section{Competing Interests}

The authors declare that they have no competing interests.

\section{Publisher's Note}

Veterinary World remains neutral with regard to jurisdictional claims in published institutional affiliation.

\section{References}

1. Umartha, B.A. (2013) The Characteristic of Aceh Cattle. Banda Aceh: Syiah Kuala University Press. p35.

2. Statistics of Aceh Province. (2018) Livestock Population based on Type of Livestock and District/City, 2014-2015. Banda Aceh. Available from: https://www.aceh.bps.go.id/ linkTableDinamis/view/id/84. Retrieved on 08-12-2018.

3. Najee, H.B., Al-Shawii, A.M. and Abd-Al Rahman, L.Y. (2012) Bacterial contamination of imported bulls frozen semen. Al-Anbar J. Vet. Sci., 5(1): 1999-6527.

4. Meena, G.S., Raina, V.S., Gupta, A.K., Mohanty, T.K., Bhakat, M., Abdullah, M. and Bishist, R. (2015) Effect of preputial washing on bacterial load and preservability of semen in Murrah buffalo bulls. Vet. World, 8(6): 798-803.

5. Rahmi, Y., Darmawi, D., Abrar, M., Jamin, F., Fakhrurrazi, F. and Fahrimal, Y. (2015) Identification of Staphylococcus aureus in preputium and vagina of horses (Equus caballus). J. Med. Vet., 9(2): 154-158.

6. Mitra, J., Chowdhury, S., Panda, S., Chakraborty, M. and Anup, S. (2016) Microbiological evaluation of bovine frozen semen samples in West Bengal, India. Explor. Anim. Med. Res., 6(2): 185-191.

7. Hong, J., Quan, L.H., Heu, S., Jung, K.S., Han, S.W., Moon, E. and Roh, E. (2014) A new antimicrobial substance produced by Staphylococcus pasteuri isolated from vegetables. Food Sci. Biotechnol., 23(3): 983-990.

8. Kim, J., Hong, J., Lim, J.A., Heu, S. and Roh, E. (2018) Improved multiplex PCR primers for rapid identification of coagulase-negative staphylococci. Arch. Microbiol., 200(1): 73-83.

9. Tulinski, P., Fluit, A.C., Wagenaar, J.A., Mevius, D., van de Vijver, L. and Duim, B. (2012) Methicillin-resistant coagulase-negative staphylococci on pig farms as a reservoir of heterogeneous staphylococcal cassette chromosome mec elements. Appl. Environ. Microbiol., 78(2): 299-304.

10. Guimarães, F.F., Joaquim, S.F., Manzi, M.P., da Silva, R.C., Bruder-Nascimento, A.C.M., Costa, E.O. and Langoni, H. (2016) Comparison phenotypic and genotypic identification of Staphylococcus species isolated from bovine mastitis. Pesqui. Vet. Bras., 36(12): 1160-1164.

11. Sari, W.N., Darmawi, D., Safika, S. and Fahrimal, Y. (2017) Isolation and identification of cellulolytic Enterobacter from rumen of Aceh cattle. Vet. World, 10(12): 1515-1520.

12. Safika, S., Sari, W.N., Darmawi, D, Fahrimal, Y. and Santosa, S.F. (2018) Isolation and identification of a cellulolytic Bacillus from rumen of Aceh's cattle. Asian J. Microbiol. Biotech. Environ. Sci., 20(3): 798-804.

13. Balqis, U., Hambal, M., Admi, M., Safika, S., Meutia, N., Sugito, S., Dasrul, D., Abdullah, M.A.N., Lubis, T.M., Abrar, M. and Darmawi, D. (2018) Escherichia fergusonii identified in preputial swabs from healthy Aceh cattle by phylogenetic $16 \mathrm{~S}$ rRNA analysis. Malays. J. Microbiol., 14(2): 229-235.

14. Sari, W.E., Solihin, D.D. and Lestari, Y. (2014) Identification of endophytic actinomycetes from Indonesian rice plant based on $16 \mathrm{~S}$ rRNA and nifH genes analyses. Adv. Environ. Biol., 8(7): 2357-2365.

15. Baker, G.C., Smith, J.J. and Cowan, D.A. (2003) Review and re-analysis of domain-specific $16 \mathrm{~S}$ primers. J. Microbiol. Methods, 55(3): 541-555. 
16. Tamura, T. and Hatano, K. (2001) Phylogenetic analysis of the genus Actinoplanes and transfer of Actinoplanes minutisporangius Ruan et al. 1986 and "Actinoplanes atraurantiacus" to Cryptosporangium minutisporangium comb. nov. and Cryptosporangium aurantiacum spp. nov. Int. J. Syst. Evol. Microbiol., 51(Pt 6): 2119-2125.

17. Tamura, K., Peterson, D., Peterson, N., Stecher, G., Nei, M. and Kumar, S. (2011) MEGA5: Molecular evolutionary genetics analysis using maximum likelihood, evolutionary distance, and maximum parsimony methods. Mol. Biol. Evol., 28(10): 2731-2739.

18. Saitou, N. and Nei, M. (1987) The neighbor-joining method: A new method for reconstructing phylogenetic trees. Mol. Biol. Evol., 4(4): 406-425.

19. Felsenstein, J. (1985) Confidence limits on phylogenies: An approach using bootstrap. Evolution, 39(4): 783-791.

20. Grooms, D. (2006) Reproductive losses caused by bovine viral diarrhea virus and leptospirosis. Theriogenology, 66(3): 624-628.

21. Yoo, H.S. (2010) Infectious causes of reproductive disorders in cattle. J. Reprod. Dev., 56 Suppl: S53-60.

22. Yamamoto, T., Tsutsui, T., Nishiguchi, A. and Kobayashi, S. (2008) Evaluation of surveillance strategies for bovine brucellosis in Japan using a simulation model. Prev. Vet. Med., 86(1-2): 57-74.

23. Xavier, M.N., Paixao, T.A., Poester, F.P., Lage, A.P. and Santos, R.I. (2009) Pathological, immunohistochemical and bacteriological study of tissues and milk of cows and fetuses experimentally infected with Brucella abortus. $J$. Comp. Pathol., 140(2-3): 149-157.

24. Haapala, V., Pohjanvirta, T., Vahanikkila, N., Halkilahti, J., Simonen, H., Pelkonen, S., Soveri, T., Simojoki, H. and Autio, T. (2018) Semen as a source of Mycoplasma bovis mastitis in dairy herds. Vet. Microbiol., 216: 60-66.

25. Saritas, Z.K., Konak, S, Pamuk, K, Korkmaz, M., CevikDemirkan, A. and Civelek, T. (2012) Identification and antimicrobial susceptibility of microorganisms isolated from the preputium of healthy dogs. J. Anim. Vet. Adv., 11(4): 553-555.

26. Johnson, E.J., Zemanick, E.T., Accurso, F.J., Wagner, B.D., Robertson, E.C. and Harris, J.K. (2016) Molecular identification of Staphylococcus aureus in airway samples from children with cystic fibrosis. PLoS One., 11(1): e0147643.

27. Janda, J.M. and Abbott, S.L. (2007) 16S rRNA gene sequencing for bacterial identification in the diagnostic laboratory: Pluses, perils, and pitfalls. J. Clin. Microbiol., 45(9): 2761-2764

28. Stackebrandt, E. and Goebel, B.M. (1994). Taxonomic note: A place for DNA-DNA reassociation and 16S rRNA sequence analysis in the present species definition in bacteriology. Int. J. Syst. Bacteriol., 44(4): 846-849.

29. Chesneau, O., Morvan, A., Grimont, F., Labischinski, H. and El Solh, N. (1993) Staphylococcus pasteuri spp. isolation from human, animal, and food specimens. Int. J. Syst. Bacteriol., 43(2): 237-244.

30. Takahashi, T., Satoh, I. and Kikuchi, N. (1999) Phylogenetic relationships of 38 taxa of the genus Staphylococcus based on 16S rRNA gene sequence analysis. Int. J. Syst. Bacteriol., 49(Pt2): 725-728.

31. Mellman, A., Becker, K, Eiff, C.V., Keckevoet, U., Schumann, P. and Harmsen, D. (2006) Sequencing and staphylococci identification. Emerg. Infect. Dis., 12(2): 333-336.

32. Regecová, I., Pipova, M., Jevinova, P., Kmet, V., Vyrostkova, J. and Sopkova, D. (2014) Antimicrobial resistance of coagulase-negative species of staphylococci isolated from the meat of wild pheasants (Phasianus colchicus). Ital. J. Anim. Sci., 13(3): 3476.

33. Savini, V., Catavitello, C., Bianco, A., Balbinot, A. and D'Antonio, D. (2009) Epidemiology, pathogenicity and emerging resistances in Staphylococcus pasteuri: From mammals and lampreys, to man. Recent Patl. Antiinfect. Drug Discov., 4(2): 123-129.

34. Faria, C., Vaz-Moreira, I., Serapicos, E., Nunes, O.C. and Manaia, C.M. (2009) Antibiotic resistance in coagulase-negative staphylococci isolated from wastewater and drinking water. Sci. Total Environ., 407(12): 3876-3882.

35. Savini, V., Catavitello, C., Pompetti, F., Passeri, C., Di Zacomo, S., Esattore, F., Iacone, A. and D'Antonio, D. (2008) Contamination of a donated platelet unit by Staphylococcus pasteuri. J. Infect., 57(6): 494-496.

36. Rood, I.G., de Korte, D., Ramírez-Arcos, S., Savelkoul, P.H. and Pettersson, A. (2011) Distribution, origin and contamination risk of coagulase-negative staphylococci from platelet concentrates. J. Med. Microbiol., 60(Pt 5): 592-599.

37. Seng, R., Kitti, T., Thummeepak, R., Kongthai, P., Leungtongkam, U., Wannalerdsakun, S. and Sitthisak, S. (2017) Biofilm formation of methicillin-resistant coagulase-negative staphylococci (MR-CoNS) isolated from the community and hospital environments. PLoS One, 12(8): e0184172.

38. Xu, Z., Mkrtchyan, H.V. and Cutler, R.R. (2015) Antibiotic resistance and mecA characterization of coagulase-negative staphylococci isolated from three hotels in London, UK. Front. Microbiol., 9 (6): 947.

39. Marino, M., Frigo, F., Bartolomeoli, I. and Maifreni, M. (2010) Safety-related properties of staphylococci isolated from food and food environments. J. Appl. Microbiol., 110(2): 550-561. 